\section{Fundamental and applied researches in practice of leading scientific schools}

journal homepage: http://farplss.org

\title{
Effects and feelings as the basis of human autonomous poseism and as a "mechanism" for the self-organization of social ontology
}

\author{
V. Budz \\ Vasyl Stefanyk Precarpathian National University, Ivano-Frankivsk, Ukraine
}

Article info

Received 25.03.2018

Accepted 29.06.2018

Vasyl Stefanyk Precarpathian National University, IvanoFrankivsk, Ukraine

57 Shevchenko str., 76018, Ivano-Frankivsk, Ukraine

wolbu@ua.fm

Будз, В. (2018). Афекти та почуття як основа автопоезису людини та як «механізм» самоорганізації соціальної онтології.

Fundamental and applied researches in practice of leading scientific schools, 27 (3), 64-72.
Budz, V. (2018). Effects and feelings as the basis of human autonomous poseism and as a "mechanism" for the self-organization of social ontology. Fundamental and applied researches in practice of leading scientific schools, 27 (3), 64-72.

In the monograph are analyzed individual, locally-group and global levels of public self-organization in the context of correlation of rational and irrational factors of selforganization of society; the correlation of anthropological and axiological motivation of public activity. The features of self-organization and of intersubjective interactions in the context of synergic autopoiesis, that is based on the synergy of somatics, psyche and spirit are investigated. The synergic unity of a man in the context of somatics, psyche and spirit and its phenomenological essence are signified.

Keywords: levels of public self-organization; intersubjective interactions; synergy of somatics, psyche and spirit.

\section{Афекти та почуття як основа автопоезису людини та як «механізм» самоорганізації соціальної онтології}

\author{
В. Будз
}

Прикарпатський національний університет імені Василя Стефаника, Івано-Франківськ, Україна

У монографії проаналізовано індивідуальний, локально-груповий та глобальний рівні суспільної самоорганізації у контексті співвідношення раціональних та ірраціональних чинників самоорганізації суспільства, співвідношення антропологічної та аксіологічної мотивації суспільної діяльності. Досліджено особливості самоорганізації людини та інтерсуб'єктивних взаємодій у контексті синергійного автопоезису, який відбувається на основі синергії соматики, психіки та духу. Наголошується на синергійній єдності людини в контексті соматики, психіки та духу та на $\dddot{1}$ феноменологічній сутності.

Ключові слова: рівні суспільної самоорганізації; інтерсуб'єктивні взаємодії; синергійна єдність людини в контексті соматики, психіки та духу. 


\section{Вступ}

У дослідженні я обгрунтовую думку, що основою автопоезису людини та фундаментальним «механізмом» самоорганізації суспільного буття $є$ афекти і почуття, які $\epsilon$ синергійним синтезом соматики, психіки та духу. Саме в афектах i почуттях виражається безпосередня синергійна єдність соматичного, психічного та духовного аспектів людської природи. Тобто з одного боку афекти i почуття мають антропологічне походження, але 3 іншого боку вони $\epsilon$ основою соціальної онтології.

\section{Обговорення}

На моє переконання, чітких меж, відмінностей і чіткого розрізнення між соматикою, психікою та духом в людині не існує, бо вони перебувають в ній у синергійній єдності, а тому вони «взаємоперетинаються», накладаються одне на одного і фактично співпадають, ототожнюються, бо соматичне, психічне і духовне в людині взаємокорелюються.

Не існує також чіткого розрізнення між станами психічного життя людини, бо вони перебувають у структурі людської психіки єдиним цілісним «афективно-чуттєвим потоком», який важко класифікувати і виділяти на окремі складові, бо кожний афект та емоція також пов'язані безпосередньо із соматикою та духом. Я пропоную підходити до розуміння психічного життя людини і до його проявів 3 точки зору холізму, відповідно до якого неможливо об'єктивно «розділити» емоції і почуття на види, оскільки вони існують цілісно в людській антропології. Розрізнення емоцій і почуттів на види і підвиди може бути тільки умовним, гносеологічним, використовуватись для пізнавальної простоти і зручності, однак не може бути онтологічним, бо всі афекти і почуття мають цілісний зв'язок із повнотою людської антропології, а тому емоції і почуття безпосередньо пов'язані одні з одними у цілісності психічних процесів, а також пов'язані із соматичними і духовними процесами. У монографії для пізнавальної зручності і простоти емоції, почуття та афекти я узагальнюю у понятті «афективно-чуттєві стани» (АЧС), а також розрізняю негативні та позитивні афективночуттєві стани (відповідно - НАЧС та ПАЧС).

При цьому я також обгрунтовую думку, що всі афективно-чуттєві стани $\epsilon$ в тій чи іншій мірі раціонально ідентифікованими, тобто мають спрямованість до раціональності, хоча у більшості психологічних та філософських текстів спостерігається тенденція класифікувати i зараховувати афекти i почуття до ірраціональної сфери людської психіки, тобто до несвідомого. Я відстоюю думку, що афекти і почуття (АЧС) не $\epsilon$ абсолютно ірраціональними, оскільки вони для свого буття потребують раціональноі ідентифікації їх предметних змістів, а тому кожний вид АЧС інтенціонально спрямований до певного предмету афекту чи почуття. Тому АЧС - це своєрідні «форми думки», бо наприклад, такі почуття як любов, страх, надія, віра - це не суто ірраціональні феномени, бо вони у своїй феноменології протікання завжди спрямовані до певного предмету любові, страху, надії, віри, тобто людина розуміє, знає та усвідомлює, що вона любить, чого боїться, на що сподівається і у що вірить. Власне АЧС - це не просто певні психічні стани, але вони завжди пов'язані 3 реальною фізичною дією, тобто «спонукають» любити, боятись, сподіватись, вірити, а це вже своєрідна цілеспрямована діяльність, а тому ці почуття потребують усвідомлення до чого чи до кого мали б бути спрямовані ці дії.

Афекти, емоції та почуття належать безперечно до психічної сфери, але вони «ідентифікуються» духом та відображаються безпосередньо на соматичному рівні. Тому доцільно вести мову про певну коливальну або ж нелінійну динаміку афектів i почуттів, про їx «пульсуючий» та біфуркаційний характер, який має тенденцію розпочинати свій шлях від соматичного середовища та завершуватись у духовному. Афекти і почуття одночасно грунтуються на соматичних явищах та ідентифікуються у межах духу. Тому в процесах індивідуального автопоезису та в процесах суспільної самоорганізації приймають участь не тільки афекти і почуття, але також «задіяні» соматика і психіка, тобто вся синергія людської антропології. Процеси самоорганізації суспільної дійсності хоч і мають яскраво виражений афективно-чуттєвий характер, але в цілому вони $\epsilon$ панантропологічними, бо в процесах самоорганізації «приймають» участь всі сфери людської антропології - соматика, психіка та дух. При цьому психіку людини слід розглядати як «середній термін» людської антропології, який об'єднує соматику і дух, оскільки в психіці об'єктивуються афективно-чуттєві стани, які творяться на основі соматики і духу.

Психічні явища як «середній термін» людської антропології можуть виникати не тільки під впливом фізіологічних процесів та бути залежними від гормонального рівня людського організму (тобто бути залежними від соматики), але й можуть формуватися під впливом духовних процесів на інформаційносеміотичному рівні, оскільки будь-яка семіотична інформація, яка отримується людиною сприймається нею як корисна чи шкідлива, як загрозлива чи безпечна, а така оцінка спонукає появу розмаїтих АЧС, а на їх основі опосередковано викликає певні біохімічні процеси на гормональному рівні.

Психіка суттєво детермінована духовними процесами, тобто системою світоглядно-ідеологічних явищ, які на світоглядному рівні впливають на виникнення страху, почуттів гордості, впевненості, радості, особистої чи національної гідності, або навпаки впливають на приниження і психічні стреси. Ці почуття безперечно викликають гормональні реакції організму людини. Звідси випливає, що будь-яка інформація впливає на формування АЧС, а ті впливають на біохімічний рівень людського організму. Тобто психіка людини формується та самоорганізовується одночасно під впливом фізіології (соматичних процесів) та світоглядних явищ (духовних процесів).

Психіка людини у буквальному сенсі формується під впливом матерії і духу, або «їжі» і «думок», оскільки їжа $є$ важливим чинником постачання гормонів у людський організм, а від світогляду людини залежить система самооцінки та самопочуття людини, які об'єктивуються 
у психічні явища і функціонують у формі емоцій та почуттів. В такому сенсі психіка як «середній термін» людської антропології є основним чинником, на основі якого відбувається індивідуальний автопоезис людини та самоорганізація життєдіяльності людини.

На моє переконання, фізіологічні та психічні процеси тісно пов'язані між собою у процесі автопоезису людини. Зокрема фізичне зміцнення людського організму після народження внаслідок повноцінного харчування та догляду за ним 3 боку батьків $\epsilon$ передумовою формування психічних процесів. Тобто психічні процеси в організмі людини виникають внаслідок фізичного автопоезису тіла, яке починає фізично зміцнюватись, оскільки дитина починає контролювати свої тілесні рухи, а тому такий контроль значно впливає на появу психічних явищ. Коли дитина починає самостійно сидіти, повзати, а потім ходити та контролювати біологічні процеси випорожнення організму, то фізичне зміцнення організму $\epsilon$ підгрунтям для автопоезису психіки, бо відбувається контроль з боку мозку всіх фізичних процесів. Таким чином фізичні процеси людського тіла активізують мозок людини, а той починає розвиватись вже у психічному аспекті та забезпечує формування самосвідомості. При цьому фізичний розвиток тісно пов'язаний 3 афективним розвитком дитини. Така взаємодія соматики і психіки вказує на те, що психіка виникає внаслідок тілесного автопоезису, тобто формується самостійно, виходячи із фізичних можливостей людського організму. Тому при сприятливих умовах виживання, навіть якщо б дитина розвивалась поза суспільством, то в неї з необхідністю сформувались би елементи психіки, хоча проблемним був би в такому випадку дух, оскільки абстрактному мисленню необхідно навчатись у спільноті.

Тісний зв'язок психіки i соматики в процесі їx автопоезису можна простежити на прикладі стресових ситуацій, які супроводжуються негативними АЧС. Стреси не тільки негативно впливають на психічне самопочуття, але й на фізичне самопочуття, на фізіологічні процеси людського організму, оскільки стресові ситуації «викликають» психофізичні та біохімічні реакції, які на гормональному рівні негативно впливають на фізіологічні процеси. Тому психічні стреси, які викликають зміну гормонального рівня організму впливають негативно на фізичне здоров'я людини, зокрема впливають на виникнення онкологічних захворювань. Позитивні АЧС (наприклад, сміх, радість, щастя) навпаки, є основою фізичного і психічного здоров'я та довголіття людини, оскільки вони «сприяють» на фізіологічному рівні виділенню гормонів «щастя», які діють як нейромедіатори, покращуючи біологічну життєдіяльність клітин, підвищуючи імунітет, та сприяючи таким чином, тривалості їх (клітин) життя та відповідно життя людського організму. Тому якщо дитину відповідно годувати та розвивати її в контексті позитивних АЧС, то її психічний розвиток буде успішним і швидким.

Афекти і почуття - це феномени, які є єдністю тілесного і духовного, матеріального та ідеального, буття і мислення. Вони мають «подвійну» (бінарну) природу. 3 одного боку вони $€$ спонтанними, природними (ірраціональними) і виникають на основі інстинктів людини і також фізіологічних процесів, а 3 іншого боку вони $є$ штучними, бо мають своє джерело у суспільних нормах - у свідомості, продукуються раціонально через світогляд, ідеологію, релігію, філософію. Тобто з одного боку АЧС $є$ наслідком природи людини (iї фізіології), 3 іншого боку наслідком культурного впливу, процесів виховання на основі ідей та світогляду.

В такому ракурсі афекти i почуття не $\epsilon$ суто ірраціональним, оскільки вони також формуються раціонально, при цьому ірраціональний вимір афективно-чуттєвих станів є фізіологічним, а раціональний - суспільним, культурологічним. Афекти та почуття відображають сутнісні основи людини, а тому вони є онтологічними чинниками автопоезису людини та самоорганізації суспільства і соціальних спільнот. Вони відображають єдність буття та мислення, тіла та духу, фізіологічного та психічного в людині. АЧС поєднують біологічні та соціальні аспекти людського буття.

АЧС породжуються особливостями біологічної природи людини і залежать від фізіологічних процесів. Психіка людини формується позасвідомо, ірраціонально, природним шляхом (фізіологічно) через «біохімію афектів і почуттів», $\epsilon$ залежною від гормональних процесів в людському організмі, залежною від їжі (від хімічних складників їжі і води), від впливу електромагнітних коливань та випромінювання космічного і земного, тобто від систем сил природи. Тобто АЧС безпосередньо пов'язані з фізико-хімічними властивостями людського організму, впливають на стан фізичного здоров'я. 3 фізико-хімічної та біохімічної точок зору афективно-чуттєві стани (а також людське мислення) є своєрідним «енергетичним потоком» у людському тілі. Позитивні та негативні афекти і почуття створюють певні електромагнітні енергетичні вібрації, які позитивно чи негативно впливають на речовини та енергії людського тіла, на розвиток живих клітин. Позитивні АЧС створюють підгрунтя для виникнення позитивних потоків електромагнітної енергії (можливо навіть інформації), які впливають на формування гормонів щастя, а негативні АЧС створюють потоки негативної електромагнітної енергії, які впливають на формування певного гормонального рівня (гормонів стресу), а той на формування афектів і почуттів.

3 іншого боку АЧС формуються раціонально у соціальному середовищі як результат педагогічного, естетичного, морально-правового, світоглядноідеологічного виховного впливу на людину у процесі її соціалізації. Психіка, яка об'єктивується в афектах і почуттях формується раціональним шляхом через аксіологічні системи, через ідеологічні форми. Звідси через світогляд та ідеологію та через вплив на фізіологію людини можна маніпулювати суспільством, продукуючи ті чи інші почуття, наприклад, задоволення чи незадоволення. В цілому афекти і почуття можна «посилювати» через світоглядні та фізіологічні впливи.

Афективно-чуттєві стани як «середні терміни людської антропології» $є$ одночасно сферою людського мислення та людської тілесності. Ідентифікація АЧС грунтується не тільки на раціональності, яка вказує на їх інтенціональність, (тобто вони завжди є предметними 
вираженнями людської антропології), але й на соматичній ідентифікації, оскільки корисне чи шкідливе мають значення перш за все стосовно людської тілесності. 3 іншого боку бажання, почуття, потреби, волю не можна виражати без раціонально-мовного оформлення. Всі людські бажання, емоції та почуття мають тенденцію «опредметнюватись» у мові, а отже, вони ідентифікуються раціонально.

Крім цього афективно-чуттєві стани є суспільними феноменами. Їх ідентифікація апріорно передбачає спільно-значуще відношення до когось чи чогось. Самі по собі афективно-чуттєві стани, безвідносно до оцінки іншого суспільного суб'єкта та його розуму не існують.

АЧС - це також метафізичні феномени, які існують у сфері людської ментальності як соціальні оцінки та цінності, як «віднесення» до цінностей, бо позитивні АЧС $\epsilon$ в структурі усіх цінностей, теоретичного дискурсу ідеалів та благ. Аксіологічна проблематика у своїй суті це проблематика феноменології людських почуттів. Будь-яка цінність, чи ціннісний смисл «супроводжується» позитивними АЧС. Якщо $є$ нехтування цінностями - то це водночас нехтування АЧС. В аксіологічному контексті афективно-чуттєві стани - це синтез тілесності та духовності.

Афекти і почуття (психіка) - це те, що єднає прилродне (соматичне) і соціальне (духовне) в людині, те, що $€$ основою індивідуального автопоезису, бо природа «дає» людині зі свого боку можливість формуватися афектам і почуттям на фізіологічному рівні, а з іншого боку через соціум раціонально (духовно) продукуються афекти і почуття, які мають світоглядно-ідеологічне (а в цілому аксіологічне) походження.

Якщо афекти i почуття, які продукуються ірраціонально через фізіологію людини переважно стосуються задоволення та незадоволення, щастя чи стресу, то суспільство на раціональному рівні (через світоглядно-ідеологічні та моральні, правові, релігійні, філософські аспекти) здатне продукувати набагато більше афектів і почуттів ніж природа (фізіологія). Деякі афекти і почуття $є$ суто суспільними, або навіть «штучними», і в природі не існують, наприклад, сором (встид). Система культури на рівні світоглядноідеологічних систем здатна продукувати почуття, які $\epsilon$ «інтелектуальними», тобто логічно обгрунтованими.

Природа «дає» людині хіба що два фундаментальні почуття: любов (кохання) і страх (за своє існування), які у певній мірі $є$ об'єктиваціями інстинктів - сексуального та самозбереження. Суспільство ж породжує цілу низку раціональних страхів (фобій) і цілу низку раціональних видів любові до предметів і явищ.

Афективно-чуттєві стани - це безпосередній феномен, який $є$ єдністю природного і соціального, біологічного і соціального, психічного і фізіологічного. Вони $\epsilon$ основним елементом, основним атрибутом людської екзистенції, основою моральної та правової поведінки. Саме на них спрямована «дія» моралі і права, саме на їх гармонію спрямована суспільна взаємодія. Соціальний лад, соціальна гармонія, соціальний порядок, і в цілому соціальна самоорганізація неможливі без позитивних АЧС та нівеляції негативних
АЧС. У цьому аспекті АЧС - це основні «механізми» соціальної онтології.

Афекти і почуття виражають своєрідний «конфлікт» біологічної та соціальної природи людини, конфлікт тілесного та духовного світів людської антропології. В АЧС «перетинаються» тіло і дух. Саме АЧС є «мовою» людської антропології, зокрема об’єктивацією тіла і духу. Всі явища культури відображають у тій чи іншій мірі АЧС, в тому числі i мова, яку повсякденно використовує людина.

АЧС - це онтологічні феномени, які існують у реаль $\neg$ ності, а саме в людській антропології, в психіці та духові людини. Вони $\epsilon$ «невидимими» формами індивідуального автопоезису людини, тобто становлення її як соціальної істоти, а також основою суспільного зв'язку та самоорганізації, єдністю соціального та природного в людині. Вони виникають на «зламі», на «межі» двох природ людини (матеріальної та ідеальної), виражаючи синкретичну єдність людської антропології. У виникненні та продукуванні почуттів, поперемінну перевагу мають або тілесність (соматика), або дух (свідомість), а тому АЧС є динамічними та стохастичними.

у межах людської антропології відбувається постійна «трансформація» почуттів та афектів. Вони настільки є динамічними і стохастичними, що здатні перебувати в системі споріднених почуттів та впливати на формування нових систем почуттів. Наприклад, мужність, чесність, відповідальність $€$ основою для подолання страху, і навпаки, якщо переважає страх, то він суттєво обмежує і пригнічує вище вказані чесноти. При цьому АЧС перебувають у синергетичному зв'язку між собою, тобто одні почуття можуть суттєво «корегувати» інші та впливати на їх розвиток. Будь-яке почуття чи афект завжди відчувається у системі інших почуттів та афектів. В тих чи інших ситуаціях свого психічного життя (в певний момент часу) людина відчуває не одне почуття чи афект, а систему споріднених афектів і почуттів.

Виходячи 3 таких міркувань, класифікація та ідентифікація негативних та позитивних АЧС $€$ надзвичайно важким завданням (Lersh, 2008). Тим більше, що навіть можна говорити, що взагалі $\epsilon$ тільки один загальний психічний стан, один «потік АЧС», чи одне почуття (подібне до процесу мислення), яке має різні раціонально ідентифіковані відтінки у вимірі конкретних АЧС. Тому коли йде мова про різні афективно-чуттєві стани, чи різні емоції, які відчуває людина, то тут можна здійснити помилку, яка полягає в тому, що можна намагатися класифікувати єдине почуття, єдиний психічний стан, який притаманний людині і помилково його ділити та класифікувати на різновиди. Психіка як центр афектів і почуттів є по аналогії тотожна до специфіки свідомості, яка $є$ центром думок; тобто в людині функціонує одна свідомість, яка $\epsilon$ джерелом розмаїтих думок, але всі думки, які висловлюються, функціонують у певному контексті, смислі, парадигмі. Тому всю сукупність думок можна звести всього лише до декількох парадигм. Так само і всю палітру емоцій і почуттів, які ми звикли класифікувати у власній психіці можна було звести до декількох основних (модальних) афектів та почуттів. 
Можливо насправді немає великої кількості афективних станів, емоцій та почуттів, а $є$ одне «універсальне психічне почуття», яке людина за допомогою свого розуму, (основна функція якого - класифікація), розділяє АЧС на розмаїті види, зокрема на позитивні та негативні.

Фактори людської антропології (соматика, психіка та дух) перебувають у синергійній єдності. Тому їх не слід категорично розділяти навіть на основі понять, оскільки реальну єдність соматики, психіки та духу важко описати в раціональних концептах. У цьому контексті варто було б прислухатись до міркувань Ф. Лерша, який вважає, що для почуттів «...неможливо застосувати... логічну схему родового та видового поняття...» (Lersh, 2008, p.42), оскільки «феномени, які описуються психологічними термінами, не можна залучати у просторову схему взаємовключення чи взаємовиключення. Ці терміни акцентуючі, а не детермінуючі... Багато психологічних понять мають характер акцентуації, а не розрізнення...» (Lersh, 2008, p.42), тобто «...процес творення понять психології значною мірою $є$ акцентуючим, а не детермінуючим» (Lersh, 2008, p.57). Визначення, які використовуються у психології (та й зрештою у філософії для розуміння людини, iï свідомості, психіки та духу) тільки орієнтують на певну сферу людини, але не здатні адекватно описати всю багатоманітність негативних та позитивних АЧС.

Ф. Лерш обгрунтовує ідею «інтегрального взаємозв'язку душевного життя» (Lersh, 2008, p.43). На його думку, «завдяки цьому інтегральному взаємозв'язку душевна дійсність істотно відрізняється від дійсності, яку описують природничі науки, предмет яких дозволяє їм мислити і розташовувати елементи цілого у логічній схемі як такі, що перебувають поряд один з одним і є взаємовиключними» (Lersh, 2008, p.42). Хоча ці міркування Ф. Лерш застосовує для психіки, їх можна також було б застосувати для інших факторів людської антропології зокрема, та для людини в цілому, оскільки ставити чіткі та категоричні «логічні межі» між соматикою, психікою та духом буде методологічною помилкою, яка приведе до механістичного розуміння людини.

В людині (внаслідок синергії антропологічних факторів та їх впливу на автопоезис людини) неможливо чітко «розділити» соматику і психіку, психіку і духу, дух і соматику, оскільки вони постійно «переходять» одне в одного, перебувають у синергійному зв'язку, а тому будь-який внутрішній чи зовнішній чинник, який починає перебувати у відношенні до людини може спричинити зміну всіх факторів людської антропології. Тобто «поняття може цілком успішно задовольняти вимогу ясності й чіткості, і проте не мати тих рамок, що дозволили б розташувати його у логічному просторі» (Lersh, 2008, p.42). У цьому ракурсі «...обов'язково мусимо собі усвідомити, що дуже багато різних позначень мають на увазі не різний, а один і той самий стан речей (феномен), розглядаючи його $з$ різних кутів зору» (Lersh, 2008, р.43). Ф. Лерш зазначає, що «...окремі частини душевного цілого взаємопроникні, взаємопереплетені, впливають одна на одну, і не можна мислити їх як строго взаємовиключні»
(Lersh, 2008, p.40). У цьому цілісному потоці психіки «...сприйняття, уявлення й думки, настрої і почуття, емоції і пристрасті, інстинкти й прагнення, рішення i вчинки, неможливо збагнути відокремлено від цілісності переживань» (Lersh, 2008, p.40), бо «...сприйняття, почуття i прагнення майже завжди присутні одночасно» (Lersh, 2008, p.41). При цьому Ф. Лерш вважає, що «...почуття і схильність в основному не різні феномени... вони є одним і тим самим феноменом, побаченим у різних аспектах» (Lersh, 2008, p.43). Тут можна вести мову тільки про формально-поняттєву, власне гносеологічну багатоманітність соматичних, психічних та духовних явищ. Насправді ж реальну єдність людської антропології важко класифікувати на категоричні феномени, оскільки вони перебувають у синергійній єдності. У цьому контексті погоджуюсь із міркуванням I. Карівця, який вважає, що «онтологічні практики стають синергетичними практиками, в яких поєднуються і трансформуються усі здібності та здатності людини, як фізичні й душевні, так і духовні» (Karivets, 2015).

В такому аспекті за основу методологічного аналізу індивідуального автопоезису та самоорганізації суспільного буття слід брати афективно-чуттєві стани (АЧС), оскільки АЧС - це «середній термін» людської антропології, який об'єднує соматику, психіку та дух. Останні об'єктивуються в АЧС, через які людина себе ідентифікує. Наприклад, соматика проявляється через АЧС задоволення чи незадоволення; психіка проявляється через позитивні та негативні афекти; а дух проявляється на рівні вищих почуттів, які він посилює, або пригнічує.

Реально існуючими формами людського буття є АЧС, які проявляються як екзистенціали людини, як їі переживання та оцінювання, які поєднують всі чинники людини - соматику, психіку і дух, оскільки вони взаємодоповнюються та взаємокорегуються. АЧС - це найбільш реально існуючі екзистенціали, а тому їх слід вважати основними причинами індивідуального автопоезису людини та основним «механізмом» самоорганізації суспільного буття.

В межах людської антропології відбуваються постійні «переходи» між соматикою і психікою, психікою і духом, духом і соматикою. Внаслідок цього, навіть незважаючи на те, що АЧС - це середній термін людської антропології, слід якраз вести мову про єдність антропологічних факторів, які складають основу автопоезису людини та основу для самоорганізації суспільства. Такий висновок випливає 3 того, що людська природа перебуває в єдності її елементів соматики, психіки та духу. "Ділити» та визначати ці явища людської природи звичайно можна умовно на поняттєвому рівні, але їх неможливо «розділити» у вимірі такого феномену як людина, бо людина $\epsilon$ синергією цих антропологічних феноменів. Але все ж таки повинен бути такий феномен, який водночас $\epsilon$ відображенням цієї синергії та єдності антропологічних чинників. Повинен бути такий факт людської природи, який поєднує ці елементи людської структури (соматики, психіки та духу) та відображає сутнісні ознаки людини, а також є основою її автопоезису. Таким універсальним феноменом, який відображає сутнісні 
ознаки синергії людської природи $€$ негативні та позитивні АЧС, які можна вважати основами самоорганізації суспільного та автопоезису особистого життя. У цьому сенсі міжособистісні відносини та відносини у спільноті це відносини, які складаються на основі і стосовно негативних та позитивних АЧС.

АЧС відображають всі аспекти людської природи та $€$ основами формування суспільних ідеалів, цінностей, благ, $\epsilon$ основою моральних, правових, релігійних доброчинностей, а також вказують на вади людини (за їх відсутності). У цьому сенсі АЧС $€$ основними «механізмами» автопоезису людини та суспільної самоорганізації. Тому слід вести мову не про зовнішні (об'єктивні) механізми автопоезису людини та самоорганізації суспільства, бо такі будуть мати дискретний характер, а слід вести мову про почуття, які $€$ перманентними основами автопоезису людини та самоорганізації суспільного буття, бо вони приманні природі людини повсякчас. АЧС задіюють синергію людської антропології, впливаючи на їі взаємодію та взаємоперехід, а водночас породжують почуття солідарності та єдності, або ж ксенофобії та диференціації.

Можна звичайно стверджувати, що в самоорганізації суспільного буття повинні бути задіяні об'єктивні фактори (природа, культура, історія, геополітика, наявність природних ресурсів), які в цілому $\epsilon$ незалежними від окремої людини, що людей у спільноти та суспільство «об'єднує» (тобто структурує суспільне буття) територія, мова, культура, політика, економіка, виробництво, географічні, історичні та геополітичні процеси (чи навіть трансцендентні або космологічні фактори). Але навряд чи зовнішні об'єктивні фактори здатні створювати внутрішні основи для суспільної єдності, оскільки вони не можуть бути причиною формування інтегральних почуттів, які б об'єднували суспільство. Одна і та ж сама мова, культурні надбання, географічні умови діють на всіх людей приблизно однаково, але отримується різний результат сприйняття та осмислення тих чи інших об'єктивних феноменів.

Будь-яка спільнота не може самодостатньо функціонувати без інтегративних почуттів, бо вони є основою суспільної єдності. Саме на основі почуттів та афектів можлива соціальна синергія, соціальна впорядкованість та соціальна єдність, бо АЧС є основами інтеграції між людьми у формі психічної енергії та $є$ основою самоорганізації соціальної онтології.

Почуття та афекти $\epsilon$ основним «механізмом» самоорганізації відносин у малих і великих спільнотах. У суспільстві вони $є$ основними причинами його рівноваги та становлення. При цьому організація та самоорганізація суспільних відносин, зокрема на рівні моралі і права передбачає перш за все «впорядкування» людських почуттів та афектів, оскільки якщо вони не будуть впорядковані, то суспільство буде перебувати в перманентному конфлікті. Мораль та право в більшій мірі індиферентно «ставляться» до різних типів духовних (зокрема світоглядно-ідеологічних філософських та релігійних та ін.) ідентифікацій, надаючи людині свободу думки і віри. Проте мораль і право забороняють, обмежують та пригнічують вияв
НАЧС, які $є$ дезінтеграційними. Моральні та правові заборони переважно стосуються агресивного прояву афектів і почуттів у суспільних взаємодіях.

Для гармонійного та самодостатнього розвитку будь-якого суспільства в ньому швидше шукають не компромісні ідеї, а намагаються досягнути за допомогою домовленостей і компромісу інтегральних АЧС, які б дозволили толерувати іншу думку, прийняти iii, бути солідарним 3 іншими, визнавати свободу i справедливість, прощати іншому, бути милосердним до нього та мати емпатію, які б дозволили прийняти ті чи інші види поведінки, дії. Суспільна самоорганізація полягає в пошуку талких соціально-значущих афектів та почуттів, які б «легалізували» ті чи інші форми дії і поведінки однієї людини чи групи стосовно іншої.

У суспільстві для його інтеграції більш важливими є не форми духу (не ідеологія, не світогляди), а афекти та почуття, які виникають на їхньому підгрунті, бо саме афекти легалізують дію, поведінку та різноманітні соціальні інститути (владу, гроші, мораль, право), оскільки, наприклад, для існування соціальних інститутів найважливішим соціально-значущим почуттям $\epsilon$ довіра, солідарність (які $€$ важливими чинниками формування соціального капіталу). У такому ракурсі діє своєрідний закон соціальної рівноваги у суспільній самоорганізації, який здійснюється через зрівноваження негативних та позитивних АЧС, які дозволяють зменшити конфліктність та напругу в суспільстві.

Суспільно-значущі афекти та почуття (на відміну від світогляду, норм, правил і принципів) можуть «миттєво» змінюватися. Тому періоди суспільної стабільності можуть миттєво перетворитися у конфлікти, і навпаки, незалежно від функціонування світоглядноінформаційних явищ. НАЧС та ПАЧС можуть посилюватися у суспільстві, можуть виникати та функціонувати спонтанно, стихійно, бути непрогнозованими і надзвичайно динамічними, стохастичними та нелінійними. Саме в цьому аспекті вони виступають факторами суспільної самоорганізації. Добровільна організація (самоорганізація суспільства на основі доброї волі) та добровільне самоорганізоване і спонтанне виникнення соціальних груп $\epsilon$ можливе тільки на основі позитивних афектів та почуттів (ПАЧС), які здатні інтегрувати та солідаризувати суспільство, коли воля громадян буде направлена на доброчинність та благо.

у цьому аспекті головними чинниками самоорганізації суспільного буття є не надбудова у марксистському сенсі (світоглядно-ідеологічні форми), а людські почуття та афекти. Тут погоджуюсь з думкою А. Карася, який вважає, що головними чинниками громадянського поступу $\epsilon$ «відданість суспільним справам», «громадянська солідарність», «самодисципліна», «співробітництво», «довіра», «порядність», «здатність до жертовності задля громадянського добра» (Karas, 2005, p.31). Але, зауважу, що ці феномени не $\epsilon$ елементами світогляду як раціональної форми, а $є$ феноменами психічнодуховного життя, власне позитивними АЧС.

Основою співпраці між суб'єктами суспільного буття $\epsilon$ позитивні афекти та почуття, які самоорганізовують 
суспільні відносини. 3 точки зору А. Карася, «...соціальність... окреслюється як відносно автономна царина взаємодії, зумовлена природними прагненнями людей до співпраці на основі товариськості, солідарності і доброзичливості. Вона складається як мережа громадських відносин і стосунків між людьми, що мають добровільну мотивацію...» (Karas, 2005, p.22). Тут можна стверджувати, що людина має певний природний рівень позитивних АЧС, які виникають спонтанно, виходячи з їі антропологічних якостей.

у контексті синергії елементів людської антропології, афекти і почуття - це спонтанно та самоорганізаційно впорядковані та встановлені історичним досвідом і традицією психічні стани у тій чи іншій спільноті, які дозволяють людині гармонійно існувати у ній, та які $\epsilon$ шляхом до блага і самим благом, бо такі солідарні та інтеграційні почуття визнаються (класифікуються) як цінності. При цьому аксіологічна привабливість позитивних афектів та почуттів для суспільної організації випливає 3 того, що вони створюють сприятливі умови для самореалізації людини, а тому вони «оголошуються» чеснотами та цінностями, суспільними благами.

Позитивні інтеграційні АЧС є суспільно визнаними формами суспільної взаємодії, $є$ найбільш небажаними щодо суспільного стану. Суспільство все більше прагне усувати НАЧС шляхом ізоляції їх носіїв. Шляхом усунення НАЧС $є$ теоретичне обгрунтування найбільш сприятливої світоглядно-ідеологічної системи, яка б забезпечила суспільну гармонію на основі солідарних почуттів. у цьому сенсі основним компонентом самоорганізації суспільства $є$ психічно-духовна сфера, власне негативні та позитивні АЧС, які спонтанно самоорганізовують спільноту, бо у спільноті урівноважуються почуття та афекти різних суспільних груп, які відображають екзистенційно важливі потреби людини.

НАЧС та ПАЧС $є$ безпосереднім відображенням синергійної єдності тілесних, психічних та духовних потреб людини. Тому афекти і почуття - це своєрідні «медіатори», «середні терміни», які виникають i використовуються у взаємодії між соматикою, психікою та духом, і на які соматика, психіка та дух «перетворюються», тобто «опредметнюються» в межах людської антропології. Афекти і почуття є опредметнені форми соматики, психіки та духу як антропологічних якостей людини. Саме тому вони можуть вважатися основами самоорганізації суспільного та індивідуального буття, бо поєднують (концентрують) у собі ці елементи людської антропології.

На рівні афектів та почуттів у спільноті та суспільстві самоорганізовуються всі сфери суспільства, всі види соціальних інститутів, всі форми інтерсуб'єктивних взаємодій, формуються методи реалізації антропологічних потреб людини. Всі суспільні явища грунтуються на негативних та позитивних АЧС. Усі значущі та вирішальні суспільні події протікають у межах афектів та почуттів. Негативні та позитивні АЧС $є$ основою духу та ментальності будь-якої людини та нації.

АЧС складають основу соціальної реальності, основу соціальної онтології, яка $\epsilon$ мінливою у залежності від зміни систем АЧС. Усі значущі форми соціальної організації та соціальні інститути: мораль, право, політика, релігія, філософія, мистецтво виражають та грунтуються на сутнісних ознаках людини, а саме афектах та почуттях, які $\epsilon$ відображенням синергії антропологічних чинників. Тому основою суспільного буття та самоорганізації спільнот $є$ не суто раціональні чинники, але у певній мірі ірраціональні, які мають більшу вагу у суспільних явищах. У цьому аспекті навряд чи можна погодитись із думкою О. Зіновьєва, який називає «соціальними об'єднаннями... свідомі об'єднання людей як соціальних атомів для спільних свідомих дій» (Zinoviev, 2003, p.12). Соціальні об'єднання у більшості випадків виникають спонтанно, самоорганізаційно, оскільки основою соціальних об'єднань $є$ афекти і почуття, які «створюють» основу для суспільного зв'язку. Людина підсвідомо (відповідно до своєї антропологічної природи, зокрема смертності) прагне до суспільного об'єднання, бо шукає у ньому захист, безпеку, та намагається знайти компенсацію своїх почуттів.

3 точки зору О. Зіновьєва, соціальні об'єднання «...штучно винаходяться, зберігаються (відновлюються) і еволюціонують завдяки свідомо-вольовій діяльності людей. Це не означає ніби то вони $€$ продуктами суб'єктивного свавілля людей» (Zinoviev, 2003, p.12). Проте, соціальні об'єднання не є штучними, а швидше природними (антропологічними) прагненнями людини. Соціальні об'єднання не потрібно «винаходити», бо вони виникають спонтанно, виходячи із природи людини. Що ж до еволюції соціальних об'єднань, то еволюціонують у цьому сенсі перш за все типи афектів і почуттів, на основі яких ці об’єднання виникають. Звідси соціальні об'єднання є якраз продуктами суб'єктивної волі, як одного з психологічних факторів. Основою соціуму є почуття, але почуття мають суб'єктивний вимір. Тому спільнота - це абсолютний суб'єктивізм та соліпсизм, воля i уявлення людини, які прагнуть до гармонії, спокою, щастя, безпеки.

У цілому будь-яка соціальна організація є можливою як організація на основі афективно-чуттєвих станів. Тому усі рівні та структури суспільного буття, рівні соціальної організації спільноти грунтуються на вимірах позитивних та негативних АЧС. Наприклад, тип суспільства у політичному та економічному відношенні - це тип системи АЧС, який формується на основі соціальних інститутів та світоглядно-ідеологічних схем. Тому зміна суспільства та зміна політичного режиму або економічної системи повинна бути залежною від зміни типу почуттів та морального відношення людини тих чи інших явищ.

Незалежно від рівня та ступеня соціальної організації малих чи великих спільнот, суспільств або «надсуспільств» майбутнього, соціальна сутність взаємодій між людьми буде вимірюватися співвідношенням позитивних та негативних АЧС у межах соціальної організації. Положення марксизму про суспільні форми свідомості як домінуючі та структуруючі у суспільному бутті $\epsilon$ методологічно недоцільним, бо створює помилкове підгрунтя для аналізу суті суспільного буття. Релігія, право, мораль, філософія, мистецтво (як форми суспільної свідомості 
(як надбудова у марксистському сенсі)) самі по собі не $є$ безпосередніми об'єктивними чинниками самоорганізації суспільного буття, але здійснюють опосередкований вплив на суспільство через продукування загальнозначущих АЧС. У цьому сенсі вони не форми суспільної свідомості, а форми продукування загальнозначущих почуттів та афектів.

Вся суспільна самоорганізація грунтується на АЧС, на намаганні виключити із суспільного буття НАЧС та продукувати позитивні АЧС. У будь-якому суспільстві (без виключення) позитивні АЧС $€$ найбільш бажаними. Вони $\epsilon$ найбільш оптимальними умовами життєдіяльності суспільства. Звідси позитивні АЧС отримують аксіологічний статус і отримують ранг цінностей.

Утворення соціальних спільнот відбувається відповідно до закону переваги позитивних афективночуттєвих станів, який полягає в тому, що позитивні афекти і почуття завжди $\epsilon$ найбільш бажаними та складають аксіологічну, моральну та правову основу самоорганізації суспільного буття. Тобто рано чи пізно у суспільстві встановлюється відносно стабільний рівень продукування та захисту позитивних афектів і почуттів, та всіма способами усуваються негативні АЧС. Тому всі дії людини та спільноти, апріорно направлені на усунення негативних та продукування позитивних АЧС. Жодна із спільнот у своїх формах життєдіяльності не прагне формуватися під впливом негативних афектів та моральних вад.

Позитивні афекти і почуття складають основу самоорганізації будь-якої спільноти, оскільки вони «дають» їй засоби інтеграції на основі порозуміння, довіри, солідарності. Тому якими б не були типи спільнот, у які б часи вони не існували (в тому числі в далекому майбутньому), для їхнього буття більше значення мають не світоглядно-ідеологічні схеми, а позитивні АЧС як основні шляхи самоорганізації суспільства. Тому якщо вирішувати соціальнофілософські питання в аспекті конструювання та самоорганізації суспільної реальності, то таку суспільну реальність можна конструювати та самоорганізовувати, грунтуючись на позитивних АЧС. Реальні (справжні) умови суспільних взаємодій, реальні умови та підгрунтя людської історії - це афективно-чуттєві стани. Людське буття в цьому сенсі $є$ реальністю афектів і почуттів, які властиві особистому статусу людини. Реальність людських відносин - це відносини на основі афектів і почуттів, при цьому позитивні АЧС $є$ ідеалами суспільної самоорганізації спільнот.

У процесі історичного розвитку суспільств, у результаті проб та помилок, набуття суспільствами досвіду суспільної взаємодії, суспільства із необхідністю приходять до потреби продукування позитивних АЧС, які $\epsilon$ основою гармонійного ладу та необхідним елементом соціальної самоорганізації. Усі традиційні форми суспільної взаємодії так чи інакше несуть у собі «досвід» позитивних АЧС. В цьому контексті в будьякому історичному періоді та в будь-якому народі, формуються приблизно однакові найбільш бажані позитивні афекти та почуття.

Незважаючи на те, що афекти і почуття реально функціонують тільки у вимірах суб'єктивної свідомості та психіки, вони як би це парадоксально не було сказано $\epsilon$ найбільш об'єктивними феноменами соціального буття людини, бо вони дані в досвіді людини, є реальними психічними станами, $\epsilon$ реальною волею, реальними почуттями, які впливають на соматику, психіку та дух. У цьому аспекті такі первісні елементи соціальних організацій, наприклад, сім'я та дружба, $\epsilon$ свідченням спонтанної організації суспільного буття, бо функціонування сім'ї та інституту дружби є афективночуттєве.

У контексті афективно-чуттєвих станів, як основ суспільної самоорганізації рівні суспільної організації можуть бути добровільні та примусові, грунтуватися або на позитивних, або негативних АЧС. Відносини у спільнотах переважно самоорганізовуються на основі афектів та почуттів, які $\epsilon$ основою суспільної самоорганізації, функціонування типу соціальності, чи типу відношень.

Показником такої самоорганізації суспільства на основі АЧС виступає мораль та право. Право починає вступати в дію, коли мораль не виконує функцію регулятора суспільних відносин, коли тільки на рівні афектів i почуттів не можна вирішити суспільну проблему. У цьому сенсі суспільний конфлікт - це показник відсутності позитивних АЧС. В такому аспекті розвиток будь-якого типу соціальності - це розвиток позитивних АЧС. Демократизація, лібералізація та гуманізація суспільних відносин - це перш за все зростання ступеня позитивних АЧС у спільнотах, а не поширення того чи іншого світоглядно-ідеологічного дискурсу.

Оскільки основним «механізмом» суспільної самоорганізації є афекти і почуття, то кожне суспільство $\epsilon$ непередбачуваним та стохастичним, оскільки афекти та почуття можуть «миттєво» змінитися, бо носіями афективних і почуттєвих станів є не закон, ідеологія, держава, а конкретна людина, яка має динамічну психіку та ще більш динамічний дух, який може розвиватися під впливом ідеології, або ж само розвиватися на основі самоосвіти та самовиховання.

Афекти та почуття як феномени людської сутності можуть змінюватись «миттєво». Будь-який успіх демократії та гуманності, свободи та солідарності у типі соціальних відносин у будь-який конкретний момент часу може закінчитись невдачею i розчаруванням, оскільки АЧС $\epsilon$ найбільш динамічним і стохастичним чинником соціальної онтології, саме тому будь-яке суспільство, в тому числі сучасне українське перебуває у постійному пошуку і розвитку, постійній динаміці.

У цілому, від якості АЧС, які проявляються у межах індивідуальної людської природи безпосередньо залежить якість персонального автопоезису, бо, наприклад, негативні АЧС стають причиною психічних та фізичних хвороб людини; а від якості сукупного прояву всіма громадянами АЧС в межах суспільної групи залежить якість самоорганізації суспільного буття, бо негативні АЧС диференціюють спільноту та створюють передумови для конфліктів, а позитивні АЧС інтегрують спільноту та створюють умови для солідарної, мирної і гуманної взаємодії. 


\section{Література / References}

Budz, V.P. (2017). Self-Organisation of Public Reality in the Context of it Antropological Principles and Axilogical Factors : in 5 vol. Vol. 2 : SelfOrganisation of a Man and of Intersubjective Communications as Synergical Autopoiesis of Human Antropology : Monograph. IvanoFrankivsk: Prykarpattya. nats Un-t them. V. Stefanyk. [in Ukrainian]

Lersh, F. (2008). Prolegomeny to psychology as human science. K .: Univ.Vid in PULSARI. [in Ukrainian]

Лерш, Ф. (2008). Пролегомени до психології як людинознавчої науки. К. Унів.вид-во ПУЛЬСАРИ.

Karas, A.F. (2005). Philosophy of Civil Society as an Interpretation of Freedom and Socialism: Author's Resume. dis for obtaining sciences. the degree of Dr.
Будз, В. П. (2017). Самоорганізація суспільної дійсності в контексті ї̈ антропологічних засад та аксіологічних чинників : у 5 m. T. 2 Самоорганізація людини та інтерсуб'єктивних комунікацій як синергійний автопоезис людської антропології : монографія. ІваноФранківськ : Прикарпат. нац. ун-т ім. В. Стефаника.

philos. Sciences: special 09.00.03 "Social Philosophy and Philosophy of History". Lviv. nats Un-t them. I. Franko [in Ukrainian]

Карась, А. Ф. (2005). Філософія громадянського суспільства як інтерпретація свободи і соціальності : автореф. дис. на здобуття наук. ступеня д-ра філос. наук : спец. 09.00.03 «Соціальна філософія та філософія історії». Львів. нац. ун-т ім. І. Франка. 